\section{Neutralising antibodies to interferon beta during the treatment of multiple sclerosis}

\section{G Giovannoni, F E Munschauer 3rd, F Deisenhammer}

The significance of the generation of antibodies in response to interferon beta administration is discussed

$\mathrm{P}$ atients with multiple sclerosis (MS) receiving interferon beta may develop neutralising anti-interferon beta antibodies (NABs) during treatment. These NABs are clinically relevant and reduce the clinical efficacy of interferon beta. Although there is lack of consensus on how these antibodies should be measured, the relative prevalence of NABs induced by different interferon beta products seems to be consistent between studies. Subcutaneous interferon beta-lb (Betaferon) is the most immunogenic, followed by subcutaneous interferon beta-la (Rebif), with intramuscular interferon beta-la (Avonex) being the least immunogenic. Differences between the interferon beta products with regard to their structure/ biochemistry, formulation, dose, route of administration, and dose frequency are likely to contribute to these observed differences in immunogenicity. This editorial highlights the consequences of NABs formation on the biological and clinical activity of interferon beta and the implications NABs have for the practicing neurologist and patient with MS.

\section{BACKGROUND}

Interferon beta is an established first line treatment in relapsing remitting $\mathrm{MS}^{1-5}$ As has been observed with other biological agents, ${ }^{6}$ antibodies are sometimes generated in response to interferon beta administration..$^{7-10}$ A subset of these antibodies inhibit or neutralise (NABs) the biological activity of interferon beta. This editorial will attempt to clarify technical issues of NABs measurement, the clinical significance of NABs, differences between the currently available interferon beta products, and the clinical implications of NAB development.

\section{ANTIBODIES ELICITED BY INTERFERON BETA}

An immune response against protein based drugs is not unusual. ${ }^{6}$ For example, neutralising antibodies have been reported during treatment with interferon alfa for viral hepatitis B and C, hairy cell leukaemia, and other types of cancer, ${ }^{9}{ }^{10}$ during treatment with bovine or porcine insulin for diabetes mellitus, ${ }^{11}$ with human growth hormone ${ }^{12}$ and factor VIII and IX therapy in haemophilia. ${ }^{13}$

Antibodies can be measured using a "binding assay", such as an ELISA. Only a subset of binding antibodies is neutralising. An in vitro or bioassay is required to identify NABs. A binding assay is usually used to screen patients for the presence of antibodies, before specifically screening for neutralising activity-that is, if the patient is negative for binding antibodies, there is no need to test for NABs. ${ }^{14}$ NAB positivity is defined by the ability of a serum sample to neutralise an in vitro biological activity of interferon beta. Although there are many biological activities of type I interferon, the most common assays utilise its antiviral effects or its ability to induce the MxA protein (myxovirus-resistance protein). The antiviral assay is currently the standard method recommended by the World Health Organisation ${ }^{15}$ to measure interferon activity and is based on the measurement of the virus induced cytopathic effect. Unfortunately, different laboratories often use different cell lines and viruses and hence these assays are not standardised. The MxA induction assay is becoming increasingly popular. ${ }^{16}$ Of the usual biological markers of interferon beta activity in peripheral blood (neopterin, $\beta$-2-microglobulin, 2' $5^{\prime}$ oligoadenylate synthetase, and Mx proteins (A and $\mathrm{B}))$, Mx proteins have a relatively high dose dependent specificity for type I interferons. ${ }^{914}$

\section{PROBLEMS ASSOCIATED WITH NABs ASSAYS}

(1) NABs assays are not necessarily a measure of antibodies that bind interferon beta. This can lead to false positive readings because of non-antibody factors that inhibit the antiviral activity of the interferon. ${ }^{17}$ To avoid this NAB quantisation should include serial sample dilutions along with controls for toxicity and endogenous interferon activity for each serum sample. ${ }^{18}$

(2) The NAB positivity rate varies depending on the selected sensitivity of the assay. This depends on the type of cells, the virus used, the amount of virus added, the initial dilution of the test serum, and the amount of interferon added to the assay that the antibodies must neutralise. In the case of the $\mathrm{Mx}$ assay, the method and reagents used to quantify Mx production are critical. The amount of interferon added to the bioassays is one of the more controversial aspects; adding too much interferon to the assay can lead to low NABs rates and adding too little interferon can result in identifying patients as positive when they have levels of NABs that are probably clinically irrelevant. ${ }^{19} 20$

(3) The interpretation of when a patient is NABs positive varies from study to study. Some regard positivity as being two consecutive positive results (Berlex/Schering) whereas others base positivity on a single positive result (Serono/Biogen). Furthermore, there is no consensus among the pharmaceutical industry with regard to the level of titre at which NABs become biologically relevant, ${ }^{14}{ }^{18}$ and therefore the proportion of patients developing NABs is reported using different titre cut off levels.

\section{CURRENTLY LICENSED INTERFERON BETA PRODUCTS USED IN THE TREATMENT OF MS}

Three interferon products have been marketed for the treatment of MS: Betaferon (Schering AG), which is marketed as Betaseron (Berlex Laboratories) in the United States, Avonex (Biogen), and Rebif (Ares-Serono). Product characteristics are compared in table 1. The immunogenicity of these three products has been examined in all of the phase 3 and phase 4 clinical trials. The lack of standardisation of assay techniques and definitions of seropositivity make it very difficult to compare the reported immunogenicity of the different products between clinical studies. However, a sufficient number of studies have now been performed to draw some conclusions. Among the licensed products, interferon beta- $\mathrm{lb}$ is more immunogenic than the interferon beta-la products. ${ }^{2-5}{ }^{19-22}$ The difference in immunogenicity between interferon beta-lb and interferon beta-la is not surprising given that interferon beta- $\mathrm{lb}$ has $\mathrm{a}$ cysteine to serine substitution at position 17, a deletion of the N-terminal methionine residue, and, unlike the natural protein is produced in $E$ coli bacteria and is therefore non-glycosylated. Interferon beta-la on the other hand is produced in mammalian cells, from the natural human gene sequence and is glycosylated.

Abbreviations: $M S$, multiple sclerosis; $N A B$, neutralising anti-interferon beta antibody 
Table 1 Currently licenced interferon beta products used to treat RRMS

\begin{tabular}{|c|c|c|c|}
\hline Characteristic & Betaferon/ Betaseron inteferon-1b & Avonex interferon-1a & Rebif interferon beta-1a \\
\hline Manufacturer & $\begin{array}{l}\text { Schering AG, Germany / Berlex, CA, } \\
\text { USA }\end{array}$ & Biogen, France & Ares-Serono, UK \\
\hline Approved & $\begin{array}{l}1995 \text { in Europe } \\
1994 \text { in the US }\end{array}$ & $\begin{array}{l}1997 \text { in Europe } \\
1996 \text { in the US }\end{array}$ & $\begin{array}{l}1998 \text { in Europe } \\
2002 \text { in the US }\end{array}$ \\
\hline Site of production & E coli bacteria cells & Chinese hamster ovary cells & Chinese hamster ovary cells \\
\hline Amino acid sequence & Cysteine mutation at position 17 & Identical to human inteferon beta & Identical to human IFN $\beta$ \\
\hline $\mathrm{N}$-terminal methionine & No & Yes & Yes \\
\hline Glycosylated & No & Yes & Yes \\
\hline Molecular weight & $18.5 \mathrm{kDa}$ & $22-24 \mathrm{kDa}$ & $22-24 \mathrm{kDa}$ \\
\hline Excipients & $\begin{array}{l}\text { Human serum albumin, di- and } \\
\text { mono-basic sodium phosphate, sodium } \\
\text { chloride final } \mathrm{pH} 7.2\end{array}$ & $\begin{array}{l}\text { Human serum albumin, di- and } \\
\text { monobasic sodium phosphate, sodium } \\
\text { chloride final } \mathrm{pH} 7.2\end{array}$ & $\begin{array}{l}\text { Mannitol, human serum albumin, } \\
\text { sodium acetate, acetic acid, sodium } \\
\text { chloride, final } \mathrm{pH} 3.8 \text {. }\end{array}$ \\
\hline Therapeutic use & RRMS, secondary progressive MS & RRMS & RRMS \\
\hline \multirow[t]{2}{*}{ Therapeutic effect } & $\begin{array}{l}\text { Decreases frequency and severity of } \\
\text { relapses }\end{array}$ & Decreases frequency of relapses & $\begin{array}{l}\text { Decreases frequency and severity of } \\
\text { relapses }\end{array}$ \\
\hline & Delay in time to progression of MS & Slows progression of disability & Slows progression of disability \\
\hline Therapeutic dose & $250 \mu \mathrm{g}$ & $30 \mu \mathrm{g}$ & $22 \mu g$ and $44 \mu g$ \\
\hline Specific activity & $32 \mathrm{MIU} / \mathrm{mg}$ & $>300 \mathrm{MIU} / \mathrm{mg}$ & $>300 \mathrm{MIU} / \mathrm{mg}$ \\
\hline Route of administration & Subcutaneous (SC) only & Intramuscular (IM) only & Subcutaneous (SC) only \\
\hline Bioavailability & $\begin{array}{l}\text { IM and SC effects similar in duration } \\
\text { but different in effect }\end{array}$ & $\begin{array}{l}\text { IM availability is threefold higher than } \\
\text { SC }\end{array}$ & $\begin{array}{l}\text { SC and IM produced equivalent } \\
\text { exposure to IFN } \beta\end{array}$ \\
\hline Frequency of administration & Every other day & Once weekly & Three times per week \\
\hline Average weekly dose & $875 \mu \mathrm{g}$ & $30 \mu g$ & $66 \mu \mathrm{g}$ and $132 \mu \mathrm{g}$ \\
\hline NABs production reported in & $45 \%$ & $24 \%$ in Phase III trial & $12.5-24 \%$ after 24 months \\
\hline $\begin{array}{l}\text { pivotal clinical trials conducted } \\
\text { before drug approval }\end{array}$ & $\begin{array}{l}\text { Reduction in clinical efficacy becoming } \\
\text { evident at } 18-24 \text { months }\end{array}$ & $3-5 \%$ in subsequent trials & \\
\hline Assay used for NABs analysis & CPE & CPE & CPE \\
\hline
\end{tabular}

References: The European Agency for the evaluation of medicinal products. Summary of product characteristics Avonex. Rev 1, 22 April 1999 CPMP/1063/96. The European Agency for the evaluation of medicinal products. Summary of product characteristics Betaferon (note: also Betaseron, Berlex, CA, USA). Rev 3 The European Agency for the evaluation of medicinal products. Summary of product characteristics, Rebif CPMP/0022/98.

Somewhat surprising is the reported differences in immunogenicity between the two interferon beta-la preparations, Avonex and Rebif. This may be attributable to differences in the manufacturing, storage, and formulation of these products. For example, the difference in the immunogenicity between the closely related interferon alfa-2a and interferon alfa-2b (interferon alfa-2a was approximately 10 times more immunogenic than interferon alfa-2 $b^{23}$ ) was attributed to a oxidation and aggregation of the protein during purification and storage. ${ }^{10}$ Effects of manufacturing on the immunogenicity of interferon beta-la has been observed for Avonex. The interferon beta-la Avonex preparation used in the pivotal phase 3 trial resulted in $24 \%$ of the treated patients developing NABs. ${ }^{3}$ However, the immunogenicity has subsequently decreased fivefold to between $2 \%$ and $5 \%$, presumably as a result of the introduction of a new manufacturing process for the commercial product. ${ }^{1922}$ In comparison, $12.5 \%-24 \%$ of patients treated with a the other interferon beta-la formulation (Rebif) develop NABs. ${ }^{45}$ This difference may be explained by the route, dose, and frequency of protein administration. ${ }^{18} 20$ In the OWIMS study $5.3 \%$ of patients receiving interferon beta-la (Rebif) 22 $\mu \mathrm{g}$ subcutaneously weekly developed NABs compared with 16.3\% receiving 44 $\mu \mathrm{g}$ subcutaneously weekly. ${ }^{26}$ Similarly, in a dose comparison study of interferon beta-la patients receiving $30 \mu \mathrm{g}$ by intramuscular injection weekly had a lower rate of NABs formation than the group receiving $60 \mu \mathrm{g}$ by intramuscular injection weekly, $2.2 \%$ compared with $5.8 \%$ (Professor M Clanet, platform presentation ENS 2001). In comparison in the PRISMS study of interferon beta-la (Rebif) and its extension phase, about $14 \%$ of patients receiving $44 \mu \mathrm{g}$ three times a week developed NABs compared with $24 \%$ receiving $22 \mu \mathrm{g}$ three times a week. ${ }^{25}$ The lower incidence of NABs in the high dose Rebif group may be a spurious finding as a result of persistent circulating interferon beta-la quenching or artificially lowering NABs titres. At least $10 \%$ of serum samples from patients receiving Rebif $22 \mu \mathrm{g}$ thrice weekly have detectable levels of interferon beta-la up to 48 hours after a subcutaneous injection. ${ }^{18}$ You would expect this figure to be higher with Rebif $44 \mu \mathrm{g}$ thrice weekly. Another comparison of the immunogenicity of the interferon beta-la products comes from the recently completed 12 month head to head EVIDENCE study, $25 \%$ of patients receiving Rebif $44 \mu \mathrm{g}$ thrice weekly developed NABs compared with $2 \%$ of Avonex treated patients (http://www.fda.gov/ cber/review/ifnbser030702rl.pdf). Although these results are preliminary and incomplete they are not consistent with the PRISMS study and need clarification. However, they do provide further evidence that there are differences between the two interferon beta-la products with regard to their ability to induce NABs.

\section{CLINICAL SIGNIFICANCE OF NABS TO INTERFERON BETA Efficacy}

The kinetics of NABs formation varies depending on the product and dose regimen. NABs become detectable between 3 and 18 months after the start of treatment. ${ }^{19} 28$ They appear sooner with interferon beta- $\mathrm{lb}$, with the majority of patients becoming positive six months after starting treatment, compared with interferon beta-la, in which it takes 9-15 months for the $\mathrm{NAB}$ positive rate to reach a plateau. ${ }^{18}$ Negative effect of NABs on efficacy, particularly for interferon betala, are delayed and not detectable in trials of less than a duration of two years. In the PRISMS study there were no reported difference in the clinical and MRI end points between $\mathrm{NAB}$ positive and $\mathrm{NAB}$ negative patients at two years. ${ }^{4}$ However, in the four year extension phase of the study the relapse rate was $62 \%$ higher (0.81 compared with $0.50, \mathrm{p}=0.002$ ), the median number of $\mathrm{T} 2$ active lesions was nearly five times greater ( 1.4 compared with $0.3, p<0.01$ ) and the median change from baseline in the MRI burden of disease was three times greater $(+17.6 \%$ compared with $-8.5 \%, \mathrm{p}<0.001$ ) in NAB positive compared with $\mathrm{NAB}$ negative patients. ${ }^{25}$ The $+17.6 \%$ median change from baseline in the burden of disease equates to $+4.4 \% / y e a r$ is similar to the $+5.5 \% /$ year median increase noted in the placebo treated patients within the first two years of the study. ${ }^{4}$ These data are the strongest evidence yet that interferon beta 
Table 2 Incidence of NABs to interferon beta in MS patients treated with interferon beta

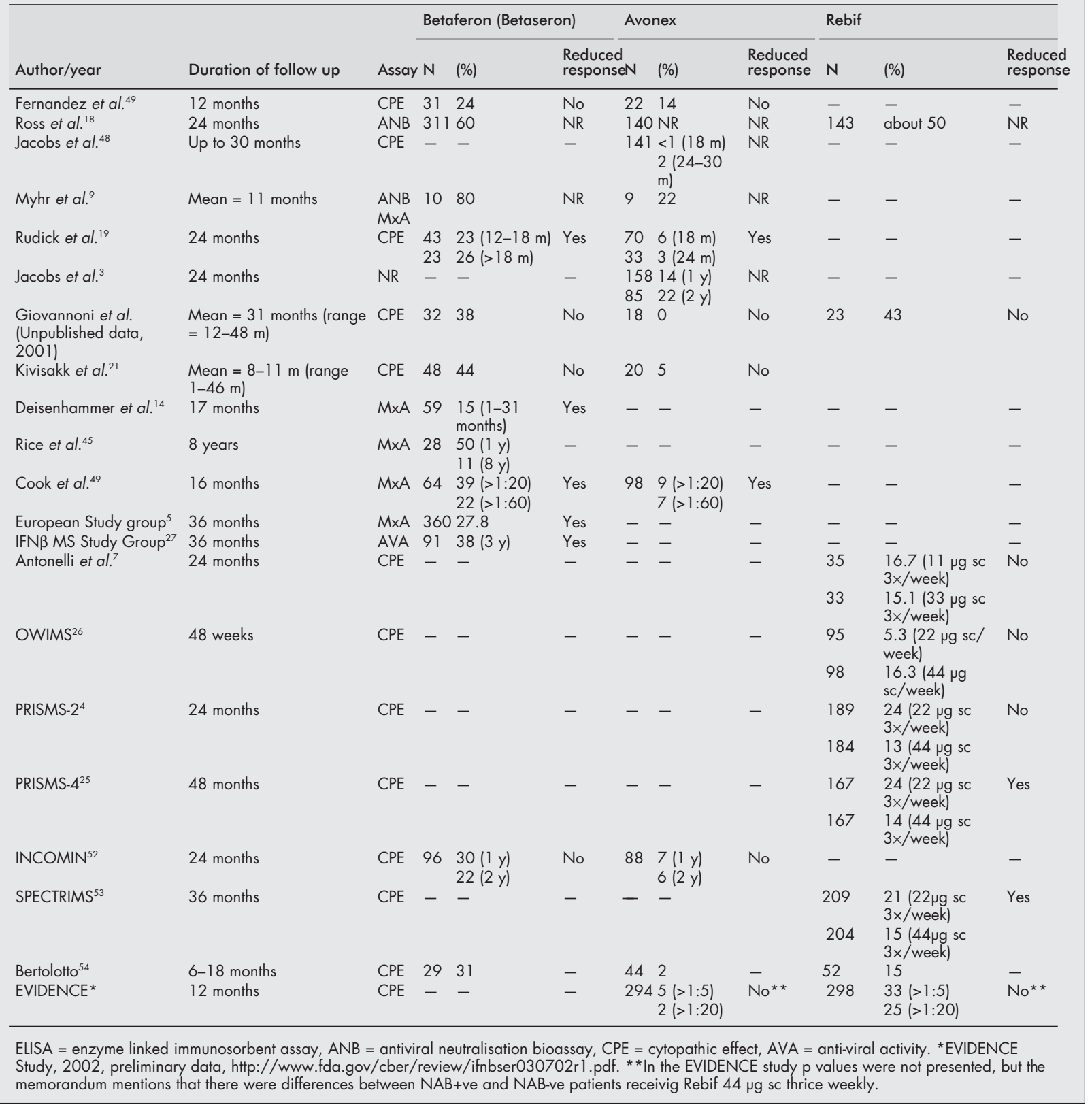

has little if any clinical and MRI efficacy in the presence of NABs.

In both neutralising and binding assays antibodies elicited in response to one interferon beta product cross reactive with other interferon beta products. ${ }^{29}{ }^{30}$ Because of the cross reactivity of the antibodies, a switch from one preparation to the other will not benefit patients while they are NAB positive.

NABs have been shown to reduce clinical efficacy of other type I interferons. It is accepted that when interferon alfa has been used to treat thrombocytosis, chronic hepatitis B and C and certain types of cancer, NABs are associated with loss of clinical effectiveness. ${ }^{8} 10$ 31-33 $\mathrm{Al}$ though the impact of NABs on the clinical effect of interferon beta initially seemed less clear than that for interferon alfa, several studies have now shown a consistent correlation between the presence of NABs and decreased efficacy (table 2). ${ }^{2} 914192527$ The effect of NABs on clinical efficacy is probably not an all or nothing phenomenon with the avidity, a measure of both titre and antibody affinity, as well as the dose of interferon playing a part. Rudick et al showed that the development of NABs to interferon beta-la (Avonex) resulted in a titre dependent reduction in neopterin and $\beta-2$ microglobulin induction. ${ }^{19}$ Others have reported similar findings with $\mathrm{Mx}$ protein. ${ }^{14}$ The beneficial shift in immune cell populations has been shown to be inhibited by NABs. Kastrukoff et al reported that MS patients who are NABs positive do not exhibit the changes in NK cell activity that interferon beta treatment normally induces. ${ }^{34}$ Perini showed that interferon beta treatment of MS patients results in a decrease in the CD16+, CD3 + cell population. ${ }^{35}$ Patients that become $\mathrm{NAB}+$ revert to pretreatment levels of these cells. ${ }^{35}$ All these studies indicate that the biological effects of interferon beta are inhibited in patients with NABs.

In the pivotal interferon beta-la (Avonex) trial, a strong trend towards reduced treatment benefit on MRI disease activity in NABs positive patients was seen. ${ }^{19}$ The PRISMS four year, ${ }^{25}$ but not two year, ${ }^{4}$ data provide the clearest correlation between positive NAB status and loss of therapeutic benefit. With interferon beta-lb (Betaseron), where 
Table 3 Clinical effect of NABs in MS patients treated with interferon beta

\begin{tabular}{|c|c|c|c|c|c|c|}
\hline & Study & $\begin{array}{l}\text { Study } \\
\text { period }\end{array}$ & Placebo & NABs- & NABs + & $\mathrm{p}$ Value \\
\hline $\begin{array}{l}\text { Betaferon/Betaseron }{ }^{27} \\
\text { Attack rate: }\end{array}$ & Phase III RRMS & 2 years & 1.06 & 0.56 & 1.08 & 0.001 \\
\hline $\begin{array}{l}\text { Avonex }{ }^{19} \\
\text { MRI-Gd lesions: mean (n) }\end{array}$ & Phase III RRMS & 2 years & $1.6(82)$ & $0.5(63)$ & $1.7(18)$ & 0.062 \\
\hline Rebif $^{25}$ & $\begin{array}{l}\text { PRISMS } \\
\text { Extension }\end{array}$ & 4 years & & & & \\
\hline Attack rate & & & NA & 0.5 & 0.81 & 0.002 \\
\hline T2-active lesions & & & NA & 0.3 & 1.4 & $<0.001$ \\
\hline $\begin{array}{l}\text { Change in T2 volume from } \\
\text { baseline }\end{array}$ & & & NA & $-8.5 \%$ & $+17.6 \%$ & $<0.001$ \\
\hline
\end{tabular}

the incidence of NABs is sufficiently high and develops earlier, ${ }^{18}$ clinical effects have been seen in two year studies (see table 3). ${ }^{27}$ As expected NAB positive patients have less systemic side effects or flu-like symptoms compared with NAB negative patients. ${ }^{27}$ No differences with regard to local or cutaneous reactions between the NABs positive and negative patients were noted. ${ }^{27}$

\section{Strategies to reduce or reverse the development of NABs}

Patients with low titres of NABs tend to become NAB negative and occasionally titres oscillate between low positive and negative over time. ${ }^{17}$ Whether these conversions or oscillations are attributable to technical aspects related for example to the timing of the sample collection in relation to treatment or represent "B cell tolerance" needs further clarification. In the case of interferon beta-lb some NAB positive patients revert to NAB negative status over two to five years of follow up. ${ }^{27}$ 36-40 Similarly, it has been reported that NAB positive interferon beta-la (Rebif) treated patients can also revert to negative status. ${ }^{37}$ In the PRISMS four year study the proportion of patients who were $\mathrm{NAB}$ positive at least once but not at the last visit was $0 \%$ with $22 \mu \mathrm{g}$ thrice weekly and $13 \%$ with $44 \mu \mathrm{g}$ thrice weekly. ${ }^{37}$ This second observation suggests a dose effect and may explain why the reversion from $\mathrm{NAB}$ positive to negative may be more commonly observed with interferon beta- $\mathrm{lb}$ (Betaferon) in which the actual quantity of interferon beta protein administered is greater - that is, $875 \mu \mathrm{g} / \mathrm{week}$ for Betaferon compared with $30 \mu \mathrm{g} /$ week for Avonex and 66 or $132 \mu \mathrm{g} /$ week for Rebif. In our experience patients with high titres of NABs seldom revert to being negative.

Reducing or reversing the development of NABs to recombinant therapeutic proteins in potentially life threatening conditions is a high priority, for example, in haemophiliac patients intensive immunosuppression is used to reverse NABs formation to factor VIII. ${ }^{41}$ In an open labelled study of $161 \mathrm{MS}$ patients, receiving interferon beta- $1 \mathrm{~b}$ (Betaferon, 8 MIU subcutaneously on alternate days), randomised to receive either intravenous methyl-prednisolone $1 \mathrm{~g}$ monthly for 12 months compared with no corticosteroids the prevalence of NABs at 15 months in the prednisone treated group was $12.1 \%$ compared with $26.8 \%$ in untreated group, a relative reduction of $54.9 \%{ }^{42}$ Interestingly, in one study in which NAB positive Betaferon patients were directly switched to Avonex, 53\% and $75 \%$ reverted to $\mathrm{NAB}$ negative after one and two years, respectively. ${ }^{43}$ Combining other immunosuppressive therapies with interferon beta, for example, azathioprine or mitoxantrone, to reduce the incidence of NABs is another strategy worthy of investigation. The induction of tolerance is the proposed mechanism that underlies the observed reduction in NABs to recombinant factor VIII when haemophiliac patients are transferred from intermittent to continuous replacement therapy $^{44}$ and may also explain the disappearance of NABs in some patients treated with higher doses of interferon beta administered more frequently.

\section{IMPLICATIONS FOR THE PRACTICING NEUROLOGIST}

The following conclusions and/or recommendations can be made:

(1) The evidence that NABs abrogate the biological and clinical effects of interferon beta is beyond reasonable doubt.

(2) NABs are cross reactive between different interferon beta products and interferon beta- $\mathrm{lb}$ is more immunogenic than interferon beta-la.

(3) The immunogenicity of the different interferon beta preparations should be one of the factors that need to considered when starting treatment.

(4) Ideally patients taking interferon beta who have ongoing disease activitythat is, frequent disabling relapsesshould be screened for NABs, particularly if the clinician is considering switching preparations and/or increasing the dose of interferon beta. If positive another treatment such as glatiramer acetate or mitoxantrone hydrochloride should be considered. Interferon therapy can only be reconsidered if the patient becomes NAB negative.
(5) Once high titre NABs have developed they tend to persist. If reversal of NABs positivity does occur it tends to be in patients with low titres.

(6) In the UK routine screening for NABs cannot be performed at present in view of the poor availability of validated assays, the lack of assay standardisation, and the lack of clinical data regarding the significance of low titre NABs.

(7) If routine screening becomes available the optimal time to test for NABs is between 6-12 months for interferon beta- $1 \mathrm{~b}$ and 12-24 months for interferon beta-la.

(8) Whether interferon beta therapy should be stopped in all patients who are $\mathrm{NAB}$ positive, irrespective of their disease activity, requires further study. This question can only be answered using standardised clinical protocols and well validated assays.

\section{CONCLUSION}

There are accumulating data that indicate that NABs are clinically relevant in MS patients receiving interferon beta therapy. Neurologists need to consider this when starting treatment and assessing treatment failures. At the same time neurologists need to keep the issue of NABs in perspective. NABs are clearly not the only reason for treatment failures. Not all patients respond to interferon beta treatment and the reasons for this are still unknown. Unfortunately, no criteria have yet been identified that reliably predict responsiveness. The issue of NABs has particular relevance in the UK in which interferon beta therapy has been deemed by the National Institute of Clinical Excellence (NICE) not to be cost effective. If interferon beta treatment were to be stopped in all patients who became NAB positive this would clearly have a positive impact on the long term cost effectiveness of interferon beta treatment.

\section{Conflicts of interests}

All authors have participated in meetings sponsored by, and received travel grants and honorariums from, pharmaceutical companies marketing treatments for multiple sclerosis; our departments have received financial support for participation in randomised controlled trials of interferon beta- $\mathrm{lb}$ (Betaferon, Schering), interferon beta-la (Avonex, Biogen; Rebif, Serono), glatiramer acetate (Copaxone, Teva), and mitoxantrone (Novatrone, Immunex) in multiple sclerosis. All authors have received honorariums for acting in an ad hoc capacity as advisors to various pharmaceutical companies who have drug development programmes for multiple sclerosis. GG is the principal investigator at the National Hospital for Neurology and Neurosurgery in a trial of Natalizumab (Antegren) sponsored by Biogen Inc; GG is chairman of the UK Medical Advisory Board of Biogen and is an ad hoc member of the European and UK Advisory boards for Biogen and Teva respectively. GG is also a member of the editorial board of a MS related publication sponsored by Serono. FD is currently a 
treating physician in the Antegren trial, sponsored by Biogen, the EVIDENCE trial, sponsored by Serono, and the BENEFIT trial, sponsored by Schering. FEM serves as an ad hoc consultant to Biogen.

J Neurol Neurosurg Psychiatry
2002;73:465-469

\section{Authors' affiliations}

G Giovannoni, Department of

Neuroinflammation, Institute of Neurology, London, UK

F E Munschauer 3rd, William C Baird Multiple Sclerosis Research Center, State University of New York at Buffalo, USA

F Deisenhammer, Department of Neurology,

University of Innsbruck, Innsbruck, Austria

Correspondence to: $\mathrm{Dr} G$ Giovannoni,

Department of Neuroinflammation, Institute of

Neurology, Queen Square, London WC1 3BG,

UK; G.Giovannoni@ion.ucl.ac.uk

\section{REFERENCES}

1 Noseworthy JH, Lucchinetti C, Rodriguez M, et al. Multiple sclerosis. N Engl J Med 2000;343:938-52.

2 Interferon beta- $1 \mathrm{~b}$ in the treatment of multiple sclerosis: final outcome of the randomized controlled trial. The IFNB Multiple Sclerosis Study Group and The University of British Columbia MS/MRI Analysis Group. Neurology 1995:45: 1277-85

3 Jacobs LD, Cookfair DL, Rudick RA, et al. Intramuscular interferon beta-la for disease progression in relapsing multiple sclerosis. The Multiple Sclerosis Collaborative Research Group (MSCRG). Ann Neurol 1996:39:285-94

4 PRISM. Randomised double-blind placebo-controlled study of interferon beta-la in relapsing/remitting multiple sclerosis. PRISMS (Prevention of Relapses and Disability by Interferon beta-la Subcutaneously in Multiple Sclerosis) Study Group. Lancet 1998;352: 1498-504.

5 European Study Group. Placebo-controlled multicentre randomised trial of interferon beta- $1 \mathrm{~b}$ in treatment of secondary progressive multiple sclerosis. European Study Group on interferon beta-1 $\mathrm{b}$ in secondary progressive MS. Lancet 1998:352:1491-7.

6 Vial T, Descotes J. Immune-mediated side-effects of cytokines in humans. Toxicology 1995; 105;31-57

7 Antonelli G, Bagnato F, Pozzilli C, et al. Development of neutralizing antibodies in patients with relapsing- remitting multiple sclerosis treated with IFN-betal a. J Interferon Cytokine Res 1998; 18:345-50.

8 Leroy V, Baud M, De Traversay C, et al. Role of anti-interferon antibodies in breakthrough occurrence during alpha $2 a$ and $2 b$ therapy in patients with chronic hepatitis $\mathrm{C}$. J Hepatol 1998;28:375-81.

9 Myhr KM, Ross C, Nyland $\mathrm{HI}$, et al. Neutralizing antibodies to interferon (IFN) alpha-2a and IFN beta- $1 \mathrm{a}$ or IFN beta- $1 \mathrm{~b}$ in MS are not cross-reactive. Neurology 2000;55: 1569-72

10 Hochuli E. Interferon immunogenicity: technical evaluation of interferon-alpha 2a. J Interferon Cytokine Res 1997;17 (suppl 1):S15-21

11 Prout, TE. The antigenicity of insulin: a review. J Chron Dis 1962:15:879-85.

12 Moore WV, Leppert P. Role of aggregated human growth hormone ( $h \mathrm{GH}$ ) in developmen of antibodies to hGH. J Clin Endocrinol Metab 1980;51:691-7.

13 Lusher JM. Hemophilia treatment. Factor VIII inhibitors with recombinant products: prospective clinical trials. Haematologica 2000;85:2-5

14 Deisenhammer F, Reindl M, Harvey J, et al. Bioavailability of interferon beta $1 \mathrm{~b}$ in MS patients with and without neutralizing antibodies. Neurology 1999;52:1239-43.

15 WHO. WHO Expert Committee on Biological Standardisation. Thirty-fifth report. WHO
Technical Report Series 725. Geneva: World Health Organisation 1985 .

16 Pungor E Jr, Files JG, Gabe JD, et al. A novel bioassay for the determination of neutralizing antibodies to IFN-beta lb. J Interferon Cytokine Res 1998; 18:1025-30.

17 Pazner B, Petkau J, Oger J. Neutralizing antibodies to interferon- $\beta$ in the treatment of multiple sclerosis. CNS Drugs 1999;3:225-43

18 Ross C, Clemmesen KM, Svenson M, et al. Immunogenicity of interferon-beta in multiple sclerosis patients: influence of preparation, dosage, dose frequency, and route of administration. Danish Multiple Sclerosis Study Group. Ann Neurol 2000;48:706-12.

19 Rudick RA, Simonian NA, Alam JA, et al Incidence and significance of neutralizing antibodies to interferon beta- la in multiple sclerosis. Multiple Sclerosis Collaborative Research Group (MSCRG). Neurology 1998;50: 1266-72

20 Perini P, Facchinetti A, Bulian P, et al. Interferon-beta (INF-beta) antibodies in interferon-be. Eur Cytokine Netw 2001;12:56-61.

21 Kivisakk P, Alm GV, Fredrikson S, et al. Neutralizing and binding anti-interferon-beta (IFN-beta) antibodies. A comparison betwee IFN-beta- $\mathrm{l} a$ and IFN-beta- $1 \mathrm{~b}$ treatment in multiple sclerosis. Eur J Neurol 2000; 7:27-34

22 Jacobs LD, Beck RW, Simon JH, et al. Intramuscular interferon beta-la therapy initiated during a first demyelinating event in multiple sclerosis. CHAMPS Study Group. $N$ Engl J Med 2000;343:898-904.

23 Runkel L, Meier W, Pepinsky RB, et al. Structural and functional differences between glycosylated and non- glycosylated forms of human interferon-beta (IFN-beta). Pharmacol Res 1998;15:641-9.

24 Braun DP, Preisler HD. Cytolytic activity of peripheral blood blast cells from patients with acute myeloid leukemia. Leuk Lymphoma 1997:27:459-67.

25 PRISMS-4. Long-term efficacy of interferon-beta- 1 a in relapsing MS. Neurology 2001;56:1628-36.

26 OWIMS. Evidence of interferon beta- la dose response in relapsing-remitting MS: the OWIMS Study. The Once Weekly Interferon for MS Study Group. Neurology 1999;53:679-86.

27 IFNB MS Study Group. Neutralizing antibodies during treatment of multiple sclerosis with interferon beta- $1 \mathrm{~b}$ : experience during the first three years. The IFNB Multiple Sclerosis Study Group and the University of British Columbia MS/MRI Analysis Group. Neurology 1996;47:889-94.

28 Rice G. The significance of neutralizing antibodies in patients with multiple sclerosis treated with interferon beta. Arch Neurol 2001;58:1297-8

29 Khan OA, Dhib-Jalbut SS. Neutralizing antibodies to interferon beta- la and interferon beta- $1 \mathrm{~b}$ in MS patients are cross-reactive. Neurology 1998;51:1698-702.

30 Antonelli G, Simeoni E, Bagnato F, et al. Further study on the specificity and incidence of neutralizing antibodies to interferon (IFN) in relapsing remitting multiple sclerosis patients treated with IFN beta- 1 a or IFN beta-1b. $J$ Neurol Sci 1999;168:131-6.

31 Merup M, Engman K, Paul C. Interferon antibodies in thrombocythemia. J Interferon Res 1994;14:187-9

32 Russo D, Candoni A, Grattoni R. Clinical experience of antibodies to interferon-alpha during treatment of chronic myeloid leukemia. J Interferon Cytokine Res 1997;17 (suppl 1):S47-9.

33 1):S47-9. Interferon-alpha2a reduces MRI disease activity in relapsing-remitting multiple sclerosis. Norwegian Study Group on Interferon-alpha in Multiple Sclerosis. Neurology 1999;52:1049-56

34 Kastrukoff LF, Morgan NG, Zecchini D, et al. Natural killer cells in relapsing-remitting MS: effect of treatment with interferon beta-1B. Neurology 1999;52:351-9.

35 Perini $\mathbf{P}$, Tiberio $M$, Sivieri $S$, et al. Interleukin-1 receptor antagonist, soluble tumor necrosis factor-alpha receptor type I and II, and soluble E-selectin serum levels in multiple sclerosis patients receiving weekly intramuscular injections of interferon-betala. Eur Cytokine Netw 2000;11:81-6.

36 Petkau J, White R. Neutralizing antibodies and the efficacy of interferon beta- $1 \mathrm{~b}$ in relapsing-remitting multiple sclerosis. Mult Scler 1997;3:402.

37 Arnason BG, Toscas A, Dayal A, et al. Role of interferons in demyelinating diseases. Neural Transm Suppl 1997;49:1 17-23.

38 Price C. Interferon beta in multiple sclerosis. Current policy is sensible. BM 1997;314:600-1.

39 Rice GP, Paszner B, Oger J, et al. The evolution of neutralizing antibodies in multiple sclerosis patients treated with interferon beta-1 b. Neurology 1999;52:1277-9.

40 Rice $\mathbf{G}$. The significance of neutralizing antibodies in patients with multiple sclerosis treated with interferon beta. Arch Neurol 2001;58:1297-8.

41 Lusher JM. Inhibitor antibodies to factor VIII and factor IX: management. Semin Thromb Hemost 2000;26:179-88.

42 Pozzili C Antonini G Bagnato F, et al. Monthly corticosteroids decrease neutralizing antibodies to IFNbeta I b: a randomized trial in multiple sclerosis. J Neurol 2002; 249:50-6.

43 Herndon RM, Jacobs LD, Coats ME, et al. Results of an ongoing, open-label, safety-extension study of interferon beta- 1 a (Avonex) treatment in multiple sclerosis. International Journal of Multiple Sclerosis Care 1999;2:1-6.

44 White GC, Greenwood R, Escobar M, et al. Hemophilia factor VIII therapy. Immunological tolerance. A clinical perspective.

Haematologica 2000;85: 113-16

45 Rice GP, Paszner B, Oger J, et al. The evolution of neutralizing antibodies in multiple sclerosis patients treated with interferon beta-1b. Neurology 1999;52:1277-9.

46 Sturzebecher, S, Maibauer, R, Heuner $A$, et al. Pharmacodynamic comparison of single doses of IFN-beta la and IFN-betal b in healthy volunteers. J Interferon Cytokine Res $1999 ; 19 ; 1257-64$

47 Rudick RA, Goodkin DE, Jacobs LD, et al. Impact of interferon beta-la on neurologic disability in relapsing multiple sclerosis. The Multiple Sclerosis Collaborative Research Group (MSCRG). Neurology 1997:49:358-63.

48 Munáfo A, Trinchard-Lugan II, Uraglio M, et al. Comparative pharmacokinetics and pharmacodynamics of recombinant human interferon beta-la after intramuscular and subcutaneous administration. Eur J Neurol 2001;5:187-93

49 Fernandez O, Mayorga C, Luque G, et al. Study of binding and neutralising antibodies to interferon-beta in two groups of relapsing-remitting multiple sclerosis patients. J Neurol 2001;248:383-8.

50 Jacobs LD, Beck RW, Simon JH, et al. Intramuscular interferon beta-l a therapy initiated during a first demyelinating event in multiple sclerosis. CHAMPS Study Group. N Engl J Med 2000;343:898-904

51 Cook SD, Quinless JR, Jotkowitz RN, et al. Serum IFN neutralizing antibodies and neopterin levels in a cross-section of MS patients. Neurology 2001;57:1080-4

52 Durelli $L$, Verdun E, Barbero P, et al. Every-other-day interferon beta- $1 \mathrm{~b}$ versus once-weekly interferon beta-1 for multiple sclerosis: results of a 2-year prospective randomised multicentre study (INCOMIN) Lancet 2002;359: 1453-60.

53 SPECTRIMS Study Group. Secondary progressive efficacy clinical trial of recombinant interferon-beta-la in MS (SPECTRIMS) study group. Randomized controlled trial of interferon-beta-la in secondary progressive MS: clinical results. Neurology 2001;56:1496-1504.

54 Bertolotto A Malucchi S, Sala A, et al. Differential effects of three interferon betas in neutralising antibodies in patients with multiple sclerosis: a follow up study in an independent laboratory. J Neurol Neurosurg Psychiatry 2002;73:148-53. 


\section{Surgical treatment of temporal lobe epilepsy}

\section{S F Berkovic}

It is important that presurgical evaluation of patients with temporal lobe epilepsy is carried out by multidisciplinary teams

T he paper published in this issue by Jutila et al (this issue, pp 486-94) adds to the literature regarding surgical treatment of temporal lobe epilepsy. ${ }^{1}$ This paper presents results from a national centre for adults in Finland. The strength of this report is that it has long term follow up from a relatively defined population. The benefit of temporal lobectomy in treatment of refractory temporal lobe epilepsy has been accepted for many years and a recent creative controlled trial from a Canadian group clearly established its efficacy over medical therapy. ${ }^{2}$ The efficacy of treatment appears to be maintained over the long term, although there is a significant attrition of cases who are initially seizure free for the first 12 months. However, according to the Finnish experience reported here, such late relapses generally do not represent a return to severe intractable temporal lobe epilepsy.

Can selection of cases be improved and why do not all patients respond? These issues have been central to over 100 studies of temporal lobectomy in the last decade (for review see Hennessy et al). Relatively few markers have emerged as definitively helping in choice of patients. The finding of a localised lesion on magnetic resonance imaging and a predominance of focal seizures were positively associated with good outcome by Jutila et al, findings that are supported by earlier reports. ${ }^{4}$ The current study also found earlier age of onset as predictive of good outcome, but this has not emerged as a robust factor in previous studies. ${ }^{4}$ Methodological problems in such post hoc analyses can be critical. ${ }^{4}$ Improvement in our ability to select cases for operation, and perhaps more importantly reject inappropriate cases, will await more detailed studies. However,
Jutila et al found that some of their "palliative" cases, by which they meant patients in whom there were less convincing evidence for a unilateral confined epileptogenic zone, did have a significant seizure free rate. The study emphasises the importance of a multidisciplinary team in the complex presurgical evaluation of candidates. Seizure surgery should be performed in centres with multidisciplinary expertise and experience to maximise outcomes.

J Neurol Neurosurg Psychiatry 2002;73:470

\section{Author's affiliation}

S F Berkovic, Director, Epilepsy Research Institute, Level 1, Neurosciences Building, Austin \& Repatriation Medical Centre, Banksia Street, West Heidelberg, Victoria 3081, Australia

Correspondence to: Professor S F Berkovic; s.berkovic@unimelb.edu.au

\section{REFERENCES}

1 Jutila L, Immonen A, Mervaala $E$, et al. Long term outcome of temporal lobe epilepsy surgery: analyses of 140 consecutive patients. J Neurol Neurosurg Psychiatry 2002;73:486-94.

2 Wiebe S, Blume WT, Girvin JP, et al. A randomized, controlled trial of surgery for temporal-lobe epilepsy. $N$ Engl J Med 2001;345:311-8.

3 Hennessy MJ, Elwes RDC, Binnie CD, et al. Failed surgery for epilepsy. A study of persistence and recurrence of seizures following temporal resection. Brain 2000; 123:2445-66.

4 Mclntosh AM, Wilson SJ, Berkovic SF. Seizure outcome after temporal lobectomy: current research practice and findings. Epilepsia 2001;42:1288-1307.

\section{Hippocampal atrophy and neocortical dysfunction in early Alzheimer's disease}

\section{J-C Baron}

\section{Is there a relationship between medial temporal lobe atrophy and brain dysfunction in Alzheimer's disease?}

A lthough it would appear straightforward that neuronal loss in and by itself explains the cognitive deficits in Alzheimer's disease (AD), things are considerably more complicated as shown by Garrido et al (this issue pp 50816). ${ }^{1}$ In this elegant study of nine patients with very mild $A D$, the authors assessed the relationships between hippocampal volume (assessed with structural magnetic resonance imaging (MRI) and voxel based morphometry), and the changes in cerebral perfusion (mapped with single photon emission computed tomography (SPECT)) during a verbal recognition memory task. Increasing hippocampal atrophy was associated with reduced activation of the extensive left sided network normally engaged by this episodic task, but also with increased activation in several frontal regions. They interpret these findings as suggesting that medial temporal lobe (MTL) pathology negatively modulates structures belonging to this network and reciprocally connected with the hippocampus, while also positively modulating activity in non-specific executive control centres-also indirectly connected to the hippocampal complex-probably reflecting an attempt by the $\mathrm{AD}$ brain to maintain performance by increased attentional/strategic load.

Although this study has some acknowledged limitations, the results are convincingly robust. Furthermore, they are entirely consistent with other work. Using positron emission tomography, Meguro et al reported a significant correlation between the degree of hippocampal atrophy and the severity of resting state glucose hypometabolism in the ipsilateral parietotemporal association cortex $(\mathrm{PACX}){ }^{2}$ This correlation remained significant even after controlling for degree of dementia, thus ruling out a simple effect of disease severity. This suggested that the striking PACx hypometabolism present from the very early stages of $\mathrm{AD}$ may not simply reflect the degree of local pathology but also in part a remote effect 
of MTL tau pathology. This clinical study followed an earlier work in baboons, which documented that excitotoxic damage to the rhinal cortex (the MTL area earliest affected in $\mathrm{AD}$ ) induces significant resting hypometabolism in several PACx areas. $^{3}$ The fact that this hypometabolism was correlated to the severity of declarative memory impairment suggests that these remote functional effects may have clinical relevance. Recently, Prvulovic et al ${ }^{4}$ found that the degree of atrophy in the left superior parietal lobule was correlated not only to the reduction in activation of this area during a visuospatial task, but also to increased activation of the left occipitotemporal cortex, suggesting the visual ventral stream got engaged in the task so as to compensate (efficiently, as shown by preserved performance) for dorsal stream dysfunction.

Thus, the $\mathrm{AD}$ brain demonstrates its abnormal function in two ways, firstly a reduced capacity of normally engaged networks, and secondly, in an attempt to compensate for this, an increased activation of some less affected cortical areas. Importantly, both remote functional effects appear to be modulated by the degree of atrophy in targeted areas. Although the mechanism underlying this modulatory activity remains to be addressed, it may involve altered neurotransmitter balance, for example, glutamate/ GABA, at distant synaptic relays.

What are the clinical implications of these emerging concepts? First, they suggest that the functional impairment in $\mathrm{AD}$ is not just related to local pathology, but partly reflects dysfunction elsewhere. Second, the AD brain possesses considerable functional plasticity in areas still relatively spared by the pathology. Third, and finally, activation in those remote areas may be partially restored by-for example, appropriate manipulation of neurotransmission or re-establishment of function in the MTL, while activation of the compensatory areas may be further enhanced by targeted cognitive training. Although still entirely speculative, these interventions could be both guided and monitored by functional imaging.
J Neurol Neurosurg Psychiatry 2002;73:470-471

\section{Author's affiliation}

J-C Baron, Department of Neurology, Box 83, University of Cambridge, Addenbrooke's Hospital, Hills Road, Cambridge CB2 2QQ, UK

Correspondence to: Professor J-C Baron;

jcb54@cam.ac.uk

\section{REFERENCES}

1 Garrido GEJ, Furuie SS, Buchpiguel CA, et al. Relation between medial temporal atrophy and functional brain activity during memory processing in Alzheimer's disease: a combined MRI and SPECT study. $j$ Neurol Neurosurg Psychiatry 2002;73:508-16.

2 Meguro K, Le Mestric C, Landeau B, et al. Relationships between posterior association cortex hypometabolism and hippocampal cortex hypometabolism and hippocampa Neurosurg Psychiatry 2001:71;315-21.

3 Meguro K, Blaizot X, Kondoh Y, et al. Neocortical and hippocampal glucose hypometabolism following neurotoxic lesions of the entorhinal and perirhinal cortices in the nonhuman primate as shown by PET: implications for Alzheimer's disease. Brain 1999;122:1519-31.

4 Prvulovic D, Hubl D, Sack AT, et al. Functional imaging of visuospatial processing in Alzheimer's disease. Neuroimage 2002; (in press). compared to three identified by their doctors. Patients and carers were particularly likely to value leisure activities and social interaction and they also show a consistent improvement across all goals. For physician ratings, some goals improved and others deteriorated. There was a modest, correlation between GAS scores, a global assessment, and cognitive function.

GAS represents a novel way of measuring meaningful outcomes for patients and carers in Alzheimer's disease, but there is no reason to think it would be any different for other types of dementia. Patients' expectations of treatment and their aspirations for improvement can now be documented. The technique helps us to challenge how we should measure the effects of interventions in dementia, puts the patient and their carer at the forefront of determining benefits, and also helps to challenge our assumption that every aspect of a patient's illness needs to improve for that treatment to be regarded as successful.

\section{J Neurol Neurosurg Psychiatry \\ 2002:73:471-472}

\section{Author's affiliation}

A Burns, Department of Old Age Psychiatry, University of Manchester, Education \& Research Centre, Wythenshawe Hospital, Southmoor Road, Manchester M23 9LT, UK $(-1)$, and a lot worse $(-2)$. Thus, attention is concentrated on specific problems identified by patients and their carers which become the goals of treatment. In a study of 108 patients with mild to moderate Alzheimer's disease, patients and carers identified a mean of nine goals per subject 


\section{REFERENCES}

1 Burns A, Lawlor B, Craig S. Assessment scales in old age psychiatry. London: Martin Dunitz, 1999.

2 Schneider L, Olin J. Clinical global

impressions in Alzheimer's clinical trials. Int

Psychogeriatr 1996;8:277-88.
3 Knopman DS, Knapp M, Gracon SI, et al. The Clinician Interview-Based Impression (CIBI): a clinician's global change rating scale in Alzheimer's disease. Neurology 1994:44:2315-21.

4 Rockwood K, Graham J, Fay S, for the ACADIE investigators. Goal setting and

\section{Cortical bricks and mortar}

\section{H ffytche}

\section{The cortical microanatomy of cells in retinotopic regions may determine the geometry of hallucinations}

\begin{abstract}
.. il voit les Bâtiments s'élever sous ses yeux et lui offrir toutes les Parties qui entrent dans leur Construction extérieure. ${ }^{1}$
\end{abstract}

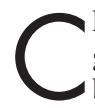
harles Bonnet's visually impaired grandfather, although rememsyndrome) for his hallucinations of figures, animals, and objects, also saw brickwork and scaffolding patterns. Largely ignored in the literature, these grid-like phenomena are experienced by more than $70 \%$ of patients with visual hallucinations secondary to eye disease. They are also reported by patients with visual pathway infarcts and by normal sighted subjects during visual sensory deprivation, stroboscopic stimulation, the hypnagogic state, and under the influence of psychedelic drugs. Their ubiquitous and stereotyped nature led Heinrich Klüver to propose that the pattern geometry reflected a fundamental visual mechanism, although he realised that its identification would await future developments in visual neuroscience. In this issue, Burke provides new psychophysical observations of his own hallucinated brickwork and dot patterns which bring us a step closer to understanding their underlying neurobiology (this issue, pp 535-41). ${ }^{2}$
Burke's hallucinations followed the development of bilateral macular holes and were seen in sufficient detail to estimate the visual angle subtended by repeating pattern elements. When transformed into cortical distance, Burke found a striking similarity between the separation of brickwork courses in his hallucinations and the separation of cytochrome oxidase stripes in the extrastriate visual cortical area, V2. Similarly, he found the separation of hallucinated dots matched the separation of cytochrome oxidase blobs in the primary visual cortex, Vl. Cytochrome oxidase staining identifies cortical subcompartments which, Burke argues, are particularly susceptible to deafferentation due to their high metabolic demands. In macaque visual cortex, Vl blobs have a higher concentration of cells specialised for colour than the surrounding interblob regions. Similarly, V2 stripes, depending on their thickness, have a higher concentration of cells specialised for orientation/direction or colour. The retinotopic organisation of $\mathrm{Vl}$ and $\mathrm{V} 2$ is such that neighbouring cells along the axis of a V2 stripe or along a row of $\mathrm{V} 1$ blobs code a specific trajectory within the visual field. Burke proposes that, following deafferentation of macular visual cortex, increased spontaneous activity in attainment in Alzheimer's disease patients treated with donepezil. J Neurol Neurosurg Psychiatry 2002;73:500-7.

5 Rockwood K, Stolee P, Howard K, et al. Use of goal attainment scaling to measure treatment effects in an anti-dementia drug trial. Neuroepidemiology 1996;15:330-8.

V2 stripes results in stereotyped brickwork hallucinations and, in Vl blobs, dot pattern hallucinations.

A link between cortical architecture and the geometry of pathological visual percepts was suggested as early as 1941 by Karl Lashley, with respect to his own migraine aura, and several anatomical explanations have been offered. ${ }^{34}$ Burke's hypothesis moves the field forward in that his is the first to account for different types of pattern hallucination and, in particular, to provide a plausible explanation for brickwork. Our current understanding of visual hallucinations is that they result from activity within populations of cells which correlate with percepts of specific visual attributes. If Burke's proposal is correct, it suggests that, in retinotopic regions at least, the cortical microanatomy of such cells defines the geometry of their associated hallucinations-in a sense, "seeing" the brain from the inside.

J Neurol Neurosurg Psychiatry 2002;73:472

\section{Author's affiliation}

D H ffytche, Institute of Psychiatry, De Crespigny Park, London SE5 8AF, UK

Correspondence to: Dr D H ffytche;

d.ffytche@iop.kcl.ac.uk

\section{REFERENCES}

1 de Morsier G. Le syndrome de Charles Bonnet: hallucinations visuelles des vieillards sans deficience mentale. Ann Med Psychol (Paris) 1967;125:677-702.

2 Burke W. The neural basis of Charles Bonnet hallucinations: a hypothesis. J Neurol Neurosurg Psychiatry 2002;73:535-41.

3 Dahlem MA, Engelmann R, Löwel S, et al. Does the migraine aura reflect cortical organization? European Journal of Neuroscience 2000;12:767-70.

4 ffytche DH, Howard RJ. The perceptual consequences of visual loss: positive pathologies of vision. Brain $1999 ; 122$ : 1247-60. 